\title{
Isolation and Characterization of Copper Tolerant Bacterial Species Habituating in Copper Mines and Study of Their Potentiality as a Plant Growth Stimulator
}

\author{
Krishnendu Majhi \\ The University of Burdwan \\ Moitri Let \\ The University of Burdwan \\ Urmi Halder \\ The University of Burdwan \\ Rajib Bandopadhyay ( $\square$ rajibindia@gmail.com ) \\ The University of Burdwan
}

\section{Research Article}

Keywords: Biosorption, Copper, CTB, PGS, SEM-EDX

Posted Date: September 13th, 2021

DOI: https://doi.org/10.21203/rs.3.rs-705506/v1

License: (c) (i) This work is licensed under a Creative Commons Attribution 4.0 International License. Read Full License 


\section{Abstract}

Copper (Cu) is a vital micronutrient for all living organisms below its toxicity limit. Various industrial activities, mining deposits, excessive use of harmful chemicals, waste discharges, and drugs are the main reason for the emerging copper concentration. Emphases of the current study were to isolate and characterize highly copper-tolerating bacterial (CTB) species from a copper-contaminated site. In enrichment culture techniques, 24 copper tolerant microbial isolates were evaluated and the maximum tolerable concentration (MTC) was determined using various concentrations of copper sulfate pentahydrate (CuSO4.5H2O) solution. Three bacterial strains named GKSM2, GKSM6, and GKSM11 were tolerant to $350 \mathrm{mg} / \mathrm{l}$ of CuSO4.5H2O. The 16S rRNA gene sequencing and phylogeny data revealed that these CTB belong to species Bacillus zanthoxyli, Bacillus stercoris, and Pseudomonas alcaliphila species. CTB showed their optimized growth at moderate salt concentration $(0.1-0.5 \mathrm{M} \mathrm{NaCl})$, temperature range $\left(20-45^{\circ} \mathrm{C}\right)$ and wide $\mathrm{pH}$ range $(\mathrm{pH} 5.0-11)$. All the strains can produce various Plant growth stimulating (PGS) traits viz., phytohormones (IAA, GA), proline, nitrogen fixation, ammonification, and antioxidant enzymes in presence and absence of $\mathrm{Cu}^{2+}$ stress. The result displays that adsorption of $\mathrm{Cu}^{2+}$ ions evidenced by TEM, SEM, and SEM-EDX analysis.

\section{Introduction}

Over the past few years, the industrial revolution has been growing rapidly, which led to unnecessary exploitation of heavy metals in the environment. Heavy metals are generally belonging to the group of metallic elements and metalloids having high molecular weight and density $\left(>5 \mathrm{~g} / \mathrm{cm}^{3}\right.$ ) (Dhaliwal et al. 2020). Natural phenomena, mining, fungicides, metallurgic processes, and different chemical industries are the main sources of heavy metal explosion that affecting the environment especially on plant growth and human health (Altimira et al. 2012). The heavy metals are non-degradable in nature, which enters the food chain through bioaccumulation and biomagnification process. Human health has become a threat due to the release of chromium, cadmium, lead, mercury, nickel, copper, and cobalt like heavy metal through industrial waste (Afzal et al. 2017).

Copper $(\mathrm{Cu})$ is a highly reactive, biologically active essential micronutrient. In the earth's crust, the percentage of copper is 0.0068. The transition metal has an atomic number 29 and an atomic mass of 63.546. It exists mainly in two forms, oxidized cupric form $\{\mathrm{Cu}$ (II)\} and reduced cuprous form $\{\mathrm{Cu}$ (I)\} (Magnani and Solioz 2007). Mineral properties of the material and the process of soil formation determine the total amount of copper in soil (Cornu et al. 2017). Various coppercontaining ores like chalcopyrite $\left(\mathrm{CuFeS}_{2}\right)$, chalcocite $\left(\mathrm{Cu}_{2} \mathrm{~S}\right)$, cuprite $\left(\mathrm{Cu}_{2} \mathrm{O}\right)$, chrysocolla $\left[(\mathrm{Cu}, \mathrm{Al})_{2} \mathrm{H}_{2} \mathrm{Si}_{2} \mathrm{O}_{5}(\mathrm{OH})_{4} \cdot 4 \mathrm{H}_{2} \mathrm{O}\right]$, malachite $\left[\mathrm{Cu}_{2} \mathrm{CO}_{3}(\mathrm{OH})_{2}\right]$, covellite (CuS), bornite $\left(2 \mathrm{Cu}_{2} \mathrm{~S}\right.$. CuS.FeS), bobkingite $\left[\mathrm{Cu}_{5} \mathrm{Cl}_{2}(\mathrm{OH})_{8} \cdot 2 \mathrm{H}_{2} \mathrm{O}\right]$, digenite $\left(\mathrm{Cu}_{9} \mathrm{~S}_{5}\right)$, etc. are the major natural sources of copper-containing soil sediments (Kokes et al. 2014; Zhappar et al. 2019). At a low concentration, copper used as micronutrient and has several biological roles for the growth and metabolism of plants, animals, and microorganisms. Whereas, high concentration of copper (EPA; $1.3 \mathrm{mg} / \mathrm{l}$ ) can be hazardous by reacting negatively on physiological and biochemical processes (Briffa et al. 2020). In a biological system, redox reactions via cuproenzymes, can transform cupric $\{\mathrm{Cu}(\mathrm{II})\}$ state into cuprous $\{\mathrm{Cu}(\mathrm{I})\}$ (Briffa et al. 2020). During this transformation process, hydroxyl radicals and superoxide has been formed that interacts with copper ions and turns into a very toxic compound that can induce breakage in DNA strand and also oxidation of lipoprotein (LDL) (Briffa et al. 2020). A higher amount of copper in the human body causes several diseases such as chronic anaemia, brain and kidney damage, stomach intestinal distress, hepatic necrosis, haemolysis, jaundice, nausea, neurodegenerative changes, etc. (Ghaed et al. 2013). The plant can also develop various copper toxicity symptoms such as root tissue damage, increased permeability of the root cell membrane, reduced photosynthetic activity, and DNA damage (Mehes-Smith and Nkongolo 2015).

Microorganisms habituating heavy metal-rich environment has been acquired various mechanisms to survive like adsorption, intercellular accumulation, mineralization, precipitation, enzymatic reduction, and oxidation (Chouhan et al. 2012). Microbes have been acquired genetic determinants like transposons or plasmids to incorporate multiple genes in

Page 2/21 
their chromosome to develop copper resistance mechanisms (De et al. 2008). A widely distributed cop operon within the bacterial cell is involved in tolerate copper stress (Altimir et al. 2012). Generally, the cop operon is encoded by four structural genes like $\operatorname{cop} A, \operatorname{cop} B, \operatorname{cop} C$, and $\operatorname{cop} D$ which are induced in presence of copper ions (Rajaram et al. 2013). Additionally, the homeostasis of the copper detoxification mechanism in microbes is also evolved by metallothionein biosynthesis (Benhalima et al. 2020). Copper-containing proteins (CCPs) in bacteria help in many enzymatic functions and act as a cofactor that comprises copper ions as prosthetic groups (Stewart et al. 2019). Several exporters also have been reported in bacteria-mediated copper transport systems. Copper ions were generally transported on outer membrane via porins (Andrei et al. 2020), TonB-dependent transporters like NosA/OprC (Yoneyama et al. 1996), and Cu-specific metallophores like Methanobactin (Mbn) (Kenney et al. 2018). In periplasmic space, Cu ions can be imported into the cytosol through a major facilitator superfamily transporter CcoA (CaIT) (Ekici et al. 2014; Khalfaoui-Hassani et al. 2018 ), then various copper storage proteins Cu-chaperones like CopZ and metallothioneins were helped to bind cytosolic copper with CopA1-like ATPases (Padilla-Benavides et al. 2014; Andrei et al. 2020) which ultimately reduced Cu toxicity.

The copper belt in the Singhbhum shear zone was located in the Jharkhand state of India and was known for the presence of rich mineral resources like iron, copper, gold, nickel, kyanite, and uranium (Giri and Singh 2017). In this study, we isolated extreme copper-tolerant bacterial species (CTB) from the copper mine area of East Singhbhum. Further, maximum tolerable concentration (MTC) was determined followed by phylogenetic characterization of those isolates. Phenotypic characterization was also performed. Finally, potential species were subjected to screen plant growth-promoting capabilities. The interaction of copper ions with the bacterial cell was explored by performing SEM, TEM, and SEM-EDX analysis. These selected CTB strains can be exploited further as copper tolerant-plant growth-promoting bacteria, having PGP potential for $\mathrm{Cu}^{2+}$ stress amelioration in contaminated mining soil.

\section{Materials And Methods}

\section{Sampling and isolation}

Soil samples were aseptically collected from four different copper-rich areas of Ghatsila which was a part of Singhbhum Shear Zone. Rice field near Surda mine ( $\left.22^{\circ} 33^{\prime} 2^{\prime \prime} \mathrm{N}, 86^{\circ} 26^{\prime} 22^{\prime \prime} \mathrm{E}\right)$ was considered as Site-I. Tailing of the Surda mine $\left(22^{\circ}\right.$ $\left.33^{\prime} 2^{\prime \prime} \mathrm{N}, 86^{\circ} 26^{\prime} 22^{\prime \prime} \mathrm{E}\right)$ was Site-ll. Site-III was the fresh tailing of Kenduadihi mine ( $\left.22^{\circ} 35^{\prime} 49^{\prime \prime} \mathrm{N}, 86^{\circ} 25^{\prime} 24^{\prime \prime} \mathrm{E}\right)$ and old tailing of Kenduadihi mine ( $\left.22^{\circ} 35^{\prime} 49^{\prime \prime} \mathrm{N}, 86^{\circ} 25^{\prime} 24^{\prime \prime} \mathrm{E}\right)$ was marked as Site-IV (Fig. 1). Further soil samples from four different sites were subjected to physical characterization. Moisture content, organic matter (OM), texture (wt.\% of clay, silt, and sand), pH, bulk density, cation exchange capacity (CEC), anion exchange capacity (AEC), total carbon, nitrogen, phosphate, potassium, sulphur, magnesium, and the concentration of copper, nickel, lead, and iron (NgoleJeme 2017; Fashola et al. 2020) were measured.

The collected soil samples $(0.5 \mathrm{~g})$ were serially diluted using sterile MilliQ water, spread onto Nutrient Agar (Hi-Media $\left.{ }^{\circledR}\right)$ plates supplemented with $50 \mathrm{mg} / \mathrm{l} \mathrm{CuSO}_{4} \cdot 5 \mathrm{H}_{2} \mathrm{O}$ (Himedia ${ }^{\circledR}, \mathrm{RM} 630$ ) solution, and incubated at $37^{\circ} \mathrm{C}$ for 48 hours. Appropriate single colonies with different morphology were selected and pure cultures were transferred periodically to avoid contamination and kept in $30 \% \mathrm{v} / \mathrm{v}$ glycerol stock at $4^{\circ} \mathrm{C}$ for further analysis (Naguib et al. 2019).

\section{Phenotypic characterization and molecular identification of CTB}

Colony morphology of all the selected bacterial isolates was examined onto Nutrient Agar media. Enzyme assay and carbohydrate fermentation activities of bacterial isolates were performed according to the manufacturer's instructions (Himedia ${ }^{\circledR} ;$ Merck) (Halder et al. 2020). The Gram's nature was determined using Gram staining procedures (Reddy et al. 2007) and studied under a bright-field microscope (Leica DM1000, Germany). Cell morphology was studied under an fluorescence microscope (Leica DM1000, Germany) after staining with acridine orange (Chakraborty and Das 2014). 
For phylogenetic identification, genomic DNA of the selected isolates was extracted using Zymo research fungal/bacterial DNA miniprep kit (D6005) (Halder et al. 2020). The amplification, PCR Purification, and sequencing of the isolated genomic DNA were accessed from Bionivid Technology Private Limited (https://www.bionivid.com/). The conquered arrangement of sequences was exposed to EzBioCloud database (https://www.ezbiocloud.net/), a similarity search engine for species identification, a cross-check was done using NCBI-BLAST (http://www.ncbi.nlm.nih.gov/BLAST/). The phylogenetic tree was constructed using MEGA version 7.0.26 software (Kumar et al.2016). For the reliability of the phylogenetic tree, the neighbor-joining method (Saitou and Nei 1987), verified with 500 bootstrapping replicates were used in MEGA version 7.0.26 software. Finally, the sequences of $16 \mathrm{~S}$ rRNA were submitted in GenBank of NCBI (https://www.ncbi.nlm.nih.gov/genbank/submit/).

\section{Determination of maximum tolerable concentration (MTC)}

To determine the maximum tolerable concentration (MTC) of copper, Nutrient Broths (Himediaß) were prepared by adding gradually increased concentrations $(50 \mathrm{mg} / \mathrm{l}-550 \mathrm{mg} / \mathrm{l})$ of $\mathrm{CuSO}_{4} .5 \mathrm{H}_{2} \mathrm{O}$ (Merck). $10 \mu \mathrm{L}$ freshly grown bacterial cultures were inoculated into that prepared media and cells were allowed to grow at $37^{\circ} \mathrm{C}$ for $24 \mathrm{hrs}$ (Afzal et al 2017, Devika et al. 2013). After $24 \mathrm{hrs}$ of incubation, absorbance at $600 \mathrm{~nm}$ wavelength were measured using a UV-visible spectrophotometer (Model LI-721, Lasany, India). Metal containing NB media was taken as a control. All the experiments were performed in a triplicate manner.

\section{Susceptibility of CTB against different antibiotics}

Antibiotic sensitivity assay of the bacterial strains was performed using the disc diffusion method (Bauer 1966, Halder et al. 2020). Selected bacterial strains were spreading on the Mueller Hilton Agar (Himediaß) plates (Halder et al. 2020). Different commercially available antibiotic discs (Himedia ${ }^{\circledR}$ ) like erythromycin (15 mcg), fluconazole $(25 \mathrm{mcg})$, ciprofloxacin (5.0 mcg), mezlocillin (75 mcg), penicillin G (10 IU), streptomycin (10 mcg), ceftriaxone (390mcg), ampicillin $(10 \mathrm{mcg})$, amoxicillin $(10 \mathrm{mcg})$ and levofloxacin $(5 \mathrm{mcg})$ were applied on the plates and incubated at $37^{\circ} \mathrm{C}$ for 24 hours. Significant inhibition zones (IZ) were measured using Antibiotic Zone Scale-C (PW297, Himedia®).

\section{Effect of $\mathrm{pH}$, temperature, and salt on growth of CTB}

To determine the $\mathrm{pH}$, the bacterial isolates were inoculated into an $\mathrm{NB}$ medium with different $\mathrm{pH}$ ranges ( $\mathrm{pH}$ values 5.0, 6.0, 7.0, 8.0, 9.0, 10, and 11) using $0.2(\mathrm{M}) \mathrm{HCl}$ and $1(\mathrm{M}) \mathrm{NaOH}$. The conical flasks were incubated at $37^{\circ} \mathrm{C}$ for 24 hours. To study the effect of incubation temperature and salt tolerance ability, the procedures were the same as the determination of $\mathrm{pH}$ value. In the case of temperature, CTB was incubated at various temperatures $\left(20^{\circ} \mathrm{C}, 25^{\circ} \mathrm{C}, 30^{\circ} \mathrm{C}, 35^{\circ} \mathrm{C}, 40^{\circ} \mathrm{C}, 45^{\circ} \mathrm{C}\right)$ for 24 hours, whereas for salt tolerance ability, various $\mathrm{NaCl}$ concentrations $\{0.05(\mathrm{M}), 0.1(\mathrm{M}), 0.3(\mathrm{M}), 0.5(\mathrm{M}), 0.7(\mathrm{M})$, and 1 $(\mathrm{M})\}$ were used. All these experiments were also performed in presence of $\mathrm{Cu}^{2+}$ ions $\left(200 \mathrm{mg} / \mathrm{l} \mathrm{of} \mathrm{CuSO}_{4} \cdot 5 \mathrm{H}_{2} \mathrm{O}\right)$. After incubation, optical density (OD) values were measured using a UV-visible spectrophotometer (Model LI-721, Lasany, India) at $600 \mathrm{~nm}$. The $\mathrm{pH} 7.0$ is used as standard.

\section{Plant growth-stimulating (PGS) attributes of CTB}

\section{Indole acetic acid (IAA)}

IAA production was estimated according to Bric et al. 1991; Shreya et al. 2020. For IAA estimation, all the isolates were incubated in LB media supplemented with $0.5 \%$ tryptophan (Sigma-Aldrich Co.; Darmstadt, USA), at $37^{\circ} \mathrm{C}$ for $72 \mathrm{hr}$ in 150 rpm. Next, $2 \mathrm{ml}$ of supernatant (cell-free extract) of CTB, obtained by centrifugation at 10,000 rpm for $15 \mathrm{~min}$ at $4^{\circ} \mathrm{C}$ was thoroughly mixed with $4 \mathrm{ml}$ of Salkowski reagent ( $2 \% 0.5 \mathrm{M} \mathrm{FeCl}_{3}$ in $35 \%$ perchloric acid). After incubation for $20 \mathrm{~min}$ in dark condition, pink color was measured at $535 \mathrm{~nm}$ using a UV-visible spectrophotometer (Model LI-721, Lasany, India) on a standard curve. 


\section{Gibberellic acid (GA)}

GA production was determined according to Abou-Aly et al. 2019. For GA estimation, isolates were incubated in LB media at $37^{\circ} \mathrm{C}$ for $72 \mathrm{hr}$ at $150 \mathrm{rpm}$. Next, $1 \mathrm{ml}$ of supernatant (cell-free extract) of CTB was mixed with $1 \mathrm{ml}$ of Folin-Ciocalteu reagent (Himedia $\left.{ }^{\circledR} ; \mathrm{RM} 10822\right)$ and $1 \mathrm{ml}$ of concentrated $\mathrm{HCl}$ and makes the volume up to $6 \mathrm{ml}$ with dd $\mathrm{H}_{2} \mathrm{O}$. Afterward, the mixture was placed in the water bath for $5 \mathrm{~min}$ at $95^{\circ} \mathrm{C}$. After cooling, the absorbance was taken at $760 \mathrm{~nm}$.

\section{Proline}

The capability of CTB to produce proline was determined using the method as described by Abou-Aly et al. 2019; Theriappan et al. 2011. The bacterial isolates were incubated in LB media at $37^{\circ} \mathrm{C}$ for $72 \mathrm{hr}$ at $150 \mathrm{rpm}$. After that, $2 \mathrm{ml}$ of supernatant (cell-free extract) of CTB was mixed with $2 \mathrm{ml}$ of acid ninhydrin solution $22.5 \mathrm{~g}$ ninhydrin in $40 \mathrm{ml} 6$ (M) phosphoric acid and $60 \mathrm{ml}$ glacial acetic acid\} and $2 \mathrm{ml}$ of glacial acetic acid. Then, the mixture was placed in a water bath for 1 hour at $95^{\circ} \mathrm{C}$ and allowing them for cooled in an ice bath. After cooling, $4 \mathrm{ml}$ toluene was added to the mixture and vigorously mixed for $15-20 \mathrm{sec}$. at room temperature. The toluene was separated from the mixture and finally absorbance was taken at $520 \mathrm{~nm}$ using toluene as a control.

\section{Ammonia and Nitrogen}

Qualitative estimation of ammonia production of CTB was assessed using a peptone water medium (Cappucino and Sherman 1992). The bacterial isolates were incubated at $37^{\circ} \mathrm{C}$ for $72 \mathrm{hr}$ at $150 \mathrm{rpm}$. After that, $0.5 \mathrm{ml}$ of Nessler's reagent was added in $1 \mathrm{ml}$ of bacterial supernatant and the yellow to brown color absorbance was taken at $450 \mathrm{~nm}$ using a UVvisible spectrophotometer. Similarly, the Nitrogen fixation ability of the CTB was conducted using Ashby Mannitol agar plates (Sigma-Aldrich Co.; Merck, A1840). A visible colony of CTB on the agar plate gives a positive result for nitrogen fixation.

\section{Antioxidant activity}

The non-enzymatic antioxidant producing ability of CTB was done using the following method as described by Heo et al. 2006; Abou-Aly et al. 2019. The bacterial isolates were incubated in LB media at $37^{\circ} \mathrm{C}$ for $72 \mathrm{hr}$ at $150 \mathrm{rpm}$. Then, $500 \mu \mathrm{l}$ of supernatant (cell-free extract) of CTB was mixed with 3ml of 2-DiPhenyl-2-Picryl hydrazyl hydrate (DPPH) solution (5 mg of DPPH was added with $100 \mathrm{ml}$ absolute alcohol) and incubate for $30 \mathrm{~min}$ in dark condition. After incubation, the absorbance of the mixture was measured at $517 \mathrm{~nm}$ using ascorbic acid as a standard. The percentage of antioxidant producing ability was calculated as followed by the equation:

\footnotetext{
Residual percentage of DPPH $=\frac{\text { Absorbance of control-Absorbance of sample }}{2 \text { aAbsorbance of control }} \times 100$

Inhibited percentage of DPPH $=100-$ Residual percentage of DPPH
}

The effect of $\mathrm{Cu}^{2+}$ stress on the production of PGP traits by the CTB was also tested. All the analyses were performed in a triplicate manner.

\section{Microscopic analysis}

To characterize the surface morphology and topology of the CTB, a Scanning Electron Microscope (SEM) was used and for the detection of $\mathrm{Cu}^{2+}$ ions, EDX analysis was performed (Palanivel et al. 2020; Tunali et al. 2006). For SEM analysis, samples were prepared as per the standard protocol of Prior and Perkins 1974 with some modifications. The bacterial isolates (Cu (II) untreated and treated) were inoculated on NB medium and incubated at $37^{\circ} \mathrm{C}$ overnight. After incubation, the culture was taken into Eppendorf and centrifuged at $8000 \mathrm{rpm}$ for 5 minute at $20^{\circ} \mathrm{C}$. Next, the pellet was washed twice with PBS buffer ( $\mathrm{pH} 7.2)$ and, the pellets were suspended in $1 \mathrm{ml}$ of $2.5 \%$ glutaraldehyde solution. The suspension was set 
aside at $4^{\circ} \mathrm{C}$ overnight for the fixation process followed by dehydration using ethanol grades (50-90\%). Finally, samples on the cover glass are coated with gold dust and observed under a scanning electron microscope (Hitachi; S-530, 0.8-25 kV).

For TEM analysis, the samples were prepared similarly to the SEM protocol. The samples were placed on a copper-coated carbon grid (300 mesh) and observed under a transmission electron microscope (JEOL; JEM 1400plus, $120 \mathrm{KeV}$, Japan).

\section{Results And Discussion}

\section{Isolation, phenotypic characterization and molecular identification of CTB}

Mining residues containing various heavy metals, chemicals, and toxic elements play an important role in soil pollution (Fan et al. 2018). The soil was contaminated by various heavy metals like $\mathrm{Fe}, \mathrm{Cu}, \mathrm{Ni}$, and $\mathrm{Pb}$ (Table 1). Among all, the concentration of $\mathrm{Fe}$ and $\mathrm{Cu}$ in mining soils was higher (Table 1). The microflora present in heavy metal contaminated soil had been adopted some unique features like heavy metal resistant capacity, plant growth promotion activity, protein stability, etc. (Murthy et al. 2014).

Bacteria have evolved several mechanisms to cope with heavy metal stress such as efflux, accumulation, and reduction of metal ions (Shahla et al. 2014). Sequestration of copper ions in bacteria is mediated by various copper-binding proteins. For example, CopA and CopC proteins bind with copper ions and store them in periplasm space, whereas CopB in the outer membrane (Cha and Cooksey 1991). Another example like inner membrane proteins, CopD was involved in the copper accumulation process (Cha and Cooksey 1991), whereas CopS and CopR proteins were implicated in the activation of copper resistance operon (Mills et al. 1994). Recently, metallothionein-based intracellular accumulation was also involved in the detoxification of heavy metal (Chudobova et al. 2015). These metallothioneins were implicated in the homeostasis process and detoxify copper from the bacterial cell (Benhalima et al. 2020). In the present study, copper-resistant bacteria were isolated on nutrient agar (NA) plates amended with $50 \mathrm{mg} / \mathrm{l}$ of $\mathrm{CuSO}_{4} \cdot 5 \mathrm{H}_{2} \mathrm{O}$ solution. Primarily, 24 microbial isolates were isolated from sampling sites 1-4 based on their morphological appearance of colonies on NA medium. All selected microbial isolates were tested for MTC (mg/l) based on different $\mathrm{CuSO}_{4} .5 \mathrm{H}_{2} \mathrm{O}$ concentrations (Fig. 2). Among these, 3 microbial isolates named GKSM2, GKSM6, and GKSM11 were able to tolerate maximum concentration of $\mathrm{CuSO}_{4} \cdot 5 \mathrm{H}_{2} \mathrm{O}$ above $300 \mathrm{mg} / \mathrm{l}$ and these were considered for further study. The MTC result showed that strain GKSM2 (500 mg/l) displayed the highest resistance ability towards copper ions solution, whereas the strain GKSM6 (350 mg/l) and strain GKSM11 (400 mg/l) also had a good degree of tolerance towards copper ions. The selected bacterial strains had different MTC values towards copper ions because they might have different cell wall compositions, different copper-binding proteins, and also have different resistance mechanisms.

The Gram's natures of strain GKSM2 and GKSM6 were positive (Table 2), whereas it was negative in the case of strain GKSM11 (Table 2). In fluorescence microscopic study, GKSM6 (Fig. 3c) and GKSM11 (Fig. 3b) were rod-shaped and unbranded whereas GKSM2 shows branched structure (Fig. 3a). Also, the colony morphology and biochemical tests of all the CTB were listed in (Table 2).

To determine the taxonomic position of CTB, bacterial strains were molecularly identified using 16S rRNA gene sequencing. The similarity percentage of 16S rRNA sequences was carried out using EzBioCloud database (https://www.ezbiocloud.net/). The 16S rRNA sequence of strain GKSM2 showed maximum similarity (98.47\%) with Bacillus zanthoxyli strain 1433 (Accession no. KX865140) similarly, strain GKSM6 showed maximum similarity (99.05\%) with Bacillus stercoris strain JCM 30051 (Accession no. MN536904); and strain GKSM11 showed maximum similarity (99.86 \%) with Pseudomonas alcaliphila strain JCM 10630 (Accession no. FNAE01000025) (Table S1). The comparative results of the 16S rRNA gene sequence indicated that bacterial strain GKSM2 was identified as Bacillus zanthoxyli (GenBank accession no. MW772231.1), GKSM6 as Bacillus stercoris (GenBank accession no. MW772229.1), and GKSM11 as Pseudomonas alcaliphila (GenBank accession no. MW898222.1). The evolutionary relationship between bacterial 
strains and their top hit taxon was deduced using the neighbour-joining method of a phylogenetic tree (Fig. 4). The 500 bootstrap value was distributed in number on the nodes of the phylogenetic tree.

\section{Susceptibility of CTB against different antibiotics}

Apart from heavy metal tolerant capacity, bacterial isolates GKSM2 and GKSM6 showed maximum antibiotic sensitivity against different antibiotics viz., erythromycin, ciprofloxacin, ceftriaxone, levofloxacin, mezlocillin, penicillin G, ampicillin, amoxicillin, and streptomycin (Table 3), whereas, GKSM11 showed resistance behaviour for different antibiotics (Table 3). The reason behind the resistant capacity of gram-negative bacteria GKSM11 may be efflux pump systems that help to survive them in a copper toxic environment (Thurman et al. 1989). These efflux pump systems were involved in coselection via a cross-resistance mechanism, which consequently develops bacterial antibiotic resistance system (Dickinson et al. 2019). So, it was suggested that increasing copper contamination is involved in contributing to the emergence of antibiotic-resistant bacterial strains and it showed an indirect toxicological effect on human health.

\section{Effect of $\mathrm{pH}$, temperature, and salt on growth of CTB}

The $\mathrm{pH}$ of the solution was an important parameter that affects the activity and ionization of various enzymes, the structural conformation of proteins, accessibility of metals ions, and bioremediation competence (Karthik et al. 2017; Hadiani et al. 2018). The pH range with OD (at $600 \mathrm{~nm}$ ) value 0.5 for the growth of GKSM2 and GKSM6 was between 5.0 and 9.0 with an optimum pH (pH 6.0 for GKSM2 and pH7 for GKSM6) (Fig. 5a, 5b), whereas in the case of GKSM11, the $\mathrm{pH}$ range was between 6.0 and 11.0 with an optimum at pH 7.0 (Fig. 5c). This wide type of pH ranges was also observed in Bacillus sp. 505Y11 (pH ranges from 4-10) (Üreyen et al 2020). The interaction between pH of a solution and copper ion concentration was also seen in (Fig. 5a, 5b, and 5c). Generally, acidophilic microorganisms can grow at $<3 \mathrm{pH}$ value and moderate acidophilic required $\mathrm{pH}$ 3-5 (Minegishi 2013). Whereas, alkaliphiles required pH values above 9 but they cannot grow or reduced their growth rate at pH value 6.5 (Tiquia-Arashiro and Rodrigues 2016). So, we conclude that GKSM2 and GKSM6 were moderate acidophilic and GKSM11 was alkaliphilic. But, in presence of $\mathrm{Cu}^{2+}$, the growth of these CTB was reduced as compared with controls (Fig. 5a, 5b, and $5 \mathrm{c}$ ). This would propose that both stressful environments were not favourable for the growth of the CTB.

Temperature was the important factor that helps to understand the ability of the bacteria to regulated growth rate and metabolism (Heidari et al. 2020). A previous study reported that mesophilic microorganisms could grow at a moderate temperature range from $20-45^{\circ} \mathrm{C}$ and these mesophiles showed their optimum growth temperature at $30-39^{\circ} \mathrm{C}$ (Schiraldi and Rosa 2014). When the temperature was low, chelation occurs in the internal organelles of the bacterial cell, whereas at high temperature, enzymes or proteins denature which causes bacterial cell death (Abbas et al. 2019). The temperature range for the growth of GKSM2, GKSM6, and GKSM11 was between $20^{\circ} \mathrm{C}$ to $45^{\circ} \mathrm{C}$ with an optimum value $\left(30^{\circ} \mathrm{C}\right.$ for GKSM2 and $35^{\circ} \mathrm{C}$ for GKSM6 and GKSM11) (Fig. 5d, 5e, and 5f). So, we concluded that our selected bacterial strains were mesophilic though their growth temperature was in the range between $30^{\circ} \mathrm{C}$ to $39^{\circ} \mathrm{C}$. The interaction between temperature and copper ion concentration was also seen in (Fig. 5d, 5e, and 5f).

We also observed that all the CTB were able to tolerate up to 0.7 (M) NaCl concentration (Fig. $5 \mathrm{~g}, 5 \mathrm{~h}$, and $5 \mathrm{i}$ ) and having their optimum growth in $0.1(\mathrm{M})-0.5(\mathrm{M}) \mathrm{NaCl}$. Generally, moderate halophiles can tolerate upto 1.5 (M) salinity (Menasria et al. 2019), but the salt tolerance concentration of our CTB were moderate $\{<1.5(\mathrm{M})\}$. So, it would suggest that the CTB was not true halophilic. Also, these CTB expect GKSM6 (Fig. 5h) showed higher growth rate as compared with controls in presence of $\mathrm{Cu}^{2+}$ with different $\mathrm{NaCl}$ concentrations $\{0.05-1(\mathrm{M})\}$. That means the combination of salt and copper would favourable for the growth of most of the CTB.

\section{Plant growth stimulating factors (PGSF) of CTB}


The copper tolerable bacterial isolates showed positive response to various plant growth stimulating factors like phytohormones (IAA, GA), proline, nitrogen fixation, ammonia production, and antioxidant enzyme production in presence and absence of copper ions (Table 4). The plant growth stimulating bacterial species generally reduced the toxic effect of heavy metal and helped in growth and development of plant, which result in better yielding (Rathaur et al. 2012).

IAA production was measured and showed that GKSM2 produced a maximum IAA of $32 \mu \mathrm{g} / \mathrm{ml}$. However, IAA production was increased by $50 \%$ in $\mathrm{Cu}^{2+}$ stress $(48 \mu \mathrm{g} / \mathrm{mL})$. Similarly, IAA concentration also increases in $\mathrm{Cu}^{2+}$ stress in the case of GKSM6 $(18 \mu \mathrm{g} / \mathrm{mL})$ as compared to control $(16 \mu \mathrm{g} / \mathrm{mL})$. Whereas, in the case of GKSM11, the IAA production decrease in copper stress $(12 \mu \mathrm{g} / \mathrm{mL})$ when compared to control $(15 \mu \mathrm{g} / \mathrm{mL})$. A similar reduction of IAA under $\mathrm{Cu}^{2+}$ Stress had also been reported in Pseudomonas sp. (Dimkpa et al. 2012). The IAA production might be helped the plant in improving the nutrient acquisition; root cell division and elongation; and organization of plant-bacteria interaction, which may lead to plant growth promotion in the heavy metal contaminated area (Glick et al. 2010; Tirry et al. 2018).

As for the production of gibberellic acid (GA3) and proline by CTB, the highest amount of GA3and proline was produced by GKSM6 followed by GKSM2 and GKSM11 in both presence and absence of copper ions (Table 4). Under heavy metal stress condition, proline act as an excellent metal chelator for plants and mitigated toxic effects via osmotic changes of cell, ROS enzymes production, protein and enzyme stabilization and protecting membrane integrity (Sofy et al. 2020), whereas GA3 also taken part in growth and development of plant.

Regarding the non-enzymatic antioxidant activities, all the CTB were assayed for 2,2-DiPhenyl-2-Picryl hydrazyl hydrate (DPPH) inhibition in the presence and absence of copper stress (Table 4). The maximum inhibition of DPPH was observed by GKSM 11 followed by GKSM6 and GKSM2 at a rate of $77.9 \%, 68.7 \%$, and $66.8 \%$, respectively in the case of copper stress whereas it was $70.8 \%, 71.4 \%$, and $69.8 \%$ respectively in control. The results indicate that the CTB could inhibit DPPH under normal conditions as well as $\mathrm{Cu}^{2+}$ stress (Table 4). DPPH was a compound that generates free radicals and it has been extensively used for evaluating the free radical scavenging activity of antioxidative compounds under stress conditions (Heo et al. 2006; Abou-Aly et al. 2019). The inhibition of DPPH by all the CTB was decreased in the presence of $\mathrm{Cu}^{2+}$ stress (Table 4). This type of DPPH inhibition was observed in B. cereus MG257494.1 supplemented with $\mathrm{Cu}^{2+}$ (Abou-Aly et al. 2019). Generally, the inhibition ability of the DPPH compound was determined by producing antioxidative compounds (Athukorala et al. 2003). So, our result suggested that the CTB produced fewer antioxidative compounds in $\mathrm{Cu}^{2+}$ stress as compared with control.

Furthermore, all the CTB can fix atmospheric nitrogen and positive response for ammonia production (Table 4). An adequate amount of nitrogen source increased photosynthetic enzyme activity, which ultimately improved the stress tolerance mechanism (Jalloh et al. 2009).

Because all the CTB exhibit several important PGSF traits so we concluded that these CTB are considered as potent plant growth stimulants that could potentially take part to mitigated the hazardous effect of $\mathrm{Cu}^{2+}$ and also improved crop production with increasing growth and development of crop plant.

\section{Microscopic analysis of CTB}

The surface topography of the CTB under Cu (II) treated and untreated condition was examined using SEM study. According to many workers, there was a substantial topographical difference between a treated and untreated cell. Already reported that the surface of the $\mathrm{Cu}^{2+}$ treated bacterial cells were rough, whereas the surface of the untreated bacterial cells was very clear and smooth in appearance (Kang et al. 2020). In our study, the cell wall of all the untreated CTB was smooth and very clear in appearance (Fig. 6a1, 6a2, 6b1, 6b2, 6c1, 6c2), while the treated CTB were aggregated or clumped and showed some shiny particles on the surface. Like, GKSM2 showed clumped granular materials (Fig. 6a5) and cells were distorted (Fig. 6a6); GKSM6 exhibited some protrusions resembling configuration (Fig. 6b5, 6b6) and GKSM11

Page 8/21 
showed irregular-sized cells (Fig. 6c5, 6c6). The results also suggested that all the CTB had different shape, size, and surface topography.

SEM with EDX was used to detect the immobilization of copper ions on the cell surface of bacteria. The cellular surface of a bacterial cell had been considering as the most potent sorbent that adsorbs metal ions and the cellular components like phospholipids, peptidoglycan, polysaccharides, and some proteins were involved in this process, which ultimately reduced the toxic effect of metal ions (Kang et al. 2020). Several bacterial strains like Stenotrophomonas maltophilia, Micrococcus luteus adsorbed $\mathrm{Cu}^{2+}$ as some granular material structure that might be reduced and converted into less toxic forms (Ye et al. 2013; Ruixia et al. 2002). The EDX spectral analysis of all CTB under $\mathrm{Cu}^{2+}$ treated and untreated condition showed significant results to the adsorption process. The pattern of EDX analysis after copper stress suggested that the electrostatic interaction between $\mathrm{Cu}^{2+}$ ions and bacterial cell components. Besides, $\mathrm{Cu}$ (II) peak in the EDX spectrum (Fig. $6 a 7,6 b 7,6 c 7)$ for all the CTB was very distinctive, representing $\mathrm{Cu}(\mathrm{II})$ adsorption in bacterial.

TEM analysis under-treated and untreated conditions were used for the determination of adsorption and intracellular accumulation of metal ions. In treated condition, it was observed that various black dots indicated by electron-dense materials or granules were attached to the cell surface of GKSM2 (Fig. 6a8) and GKSM6 (Fig. 6b8), whereas in GKSM11 (Fig. 6c8), the black dots were mainly deposited inside the cell, indicating the biosorption capacity of GKSM11. This type of copper sequestration mechanism was also seen in Ralstonia sp. and Bacillus sp. where $\mathrm{Cu}^{2+}$ ions were sequestrated in a clod-like structure on the boundary of the cell surface (Choi et al. 2009).

\section{Conclusion}

The present study was framed to explore copper tolerable bacteria (CTB) for plant growth promotion under $\mathrm{Cu}^{2+}$ stress $^{2}$ conditions and also define the copper adsorption process regulating the copper tolerance mechanism. Three potential bacterial species were isolated from various copper mines and were identified as Bacillus zanthoxyli strain 1433, Bacillus stercoris strain JCM 30051, and Pseudomonas alcaliphila strain JCM 10630. In addition to their adsorption of $\mathrm{Cu}^{2+}$ ions for alleviation of toxic effects, these CTB were also exhibited various plant growth stimulating attributes under both (control and treated) conditions. The results indicated that the CTB maybe act as a $\mathrm{Cu}^{2+}$ stress ameliorator, photostimulator in copper contaminated areas which has significance in environmentally sustainable development.

\section{Declarations}

\section{Acknowledgment}

The authors acknowledge UGC-Centre of Advanced Study and DST-FIST \{No. SR/FST/LS-1/2018/188 (C)\}, Department of Botany, The University of Burdwan for conducting all the research and infrastructure facilities. We are also grateful to Hindustan Copper Limited (HCL), Ghatsila, Jharkhand and Birla Institute of Technology Mesra (BIT-Mesra), Jharkhand, India for sample collecting and instrumentation facilities respectively. KM is thankful to University Grants Commission for Junior Research Fellowship (UGC-Ref. No.: 758/CSIR-UGC NET DEC. 2017), providing research fund in initial period of work. KM is grateful to the Principal, Ananda Chandra College, Jalpaiguri, University of North Benga/for pursuing research work. M.L is grateful to UGC-JRF (UGC-Ref. No.: 737/CSIR-UGC NET JUNE 2018) for providing the research fund. U.H. is thankful to SRF (state research fund of West Bengal) for the finance assistance [Fc (Sc.)/RS/SF/BOT./2017-18/22].

\section{Conflict of interest}

The authors pronounce that they have no conflict of interest.

\section{Availability of data and material}


Not applicable

\section{Code availability}

Not applicable

\section{Author contributions}

RB adopted the idea and KM collected the information and samples. KM and ML performed experiments, drafted and edited the manuscript. KM and UH finalised figures and tables. RB critically revised and finalised the manuscripts. All authors read the manuscripts and agreed for publication.

\section{Ethics approval}

Not applicable

\section{References}

1. Abbas SZ, Yee CJ, Hossain K, Ahmad A, Rafatullah M (2019) Isolation and characterization of mercury resistant bacteria from industrial wastewater. Desalin Water Treat 138:128-133.

2. Abou-Aly HE, Youssef AM, El-Meihy RM, Tawfik TA, El-Akshar EA (2019) Evaluation of heavy metals tolerant bacterial strains as antioxidant agents and plant growth promoters.

Biocatal Agric Biotechnol19:101110.

3. Afzal AM, Rasool MH, Waseem M, Aslam B (2017) Assessment of heavy metal tolerance and biosorptive potential of Klebsiella variicola isolated from industrial effluents. AMB Expr 7:1-9.

4. Altimira F, Yáñez C, Bravo G, González M, Rojas LA, Seeger M (2012) Characterization of copper-resistant bacteria and bacterial communities from copper-polluted agricultural soils of central Chile. BMC Microbiol 12:1-2.

5. Athukorala Y, Lee KW, Shahidi F, Heu MS, Kim HT, Lee JS, Jeon YJ (2003) Antioxidant efficacy of extracts of an edible red alga (Grateloupiafilicina) in linoleic acid and fish oil. J Food Lipids 10:313-327.

6. Bauer AT (1996) Antibiotic susceptibility testing by a standardized single disc method. Am J clin pathol 45:149-58.

7. Benhalima L, Amri S, Bensouilah M, Ouzrout R (2020) Heavy metal resistance and metallothionein induction in bacteria isolated from Seybouse river, Algeria. ApplEcol Environ Res 18:1721-1737.

8. Bric JM, Bostock RM, Silverstone SE (1991) Rapid in situ assay for indoleacetic acid production by bacteria immobilized on a nitrocellulose membrane. Appl Environ Microbiol 57:535-8.

9. Briffa J, Sinagra E, Blundell R (2020) Heavy metal pollution in the environment and their toxicological effects on humans. Heliyon6:e04691.

10. Cappucino JC, Sherman N (1992) Microbiology: A Laboratory Manual. New York: Benjamin/Cumming Pub. Co., California, USA

11. Cha JS, Cooksey DA (1991) Copper resistance in Pseudomonas syringae mediated by periplasmic and outer membrane proteins. Proc Natl Acad Sci 88:8915-8919.

12. Chakraborty J, Das S (2014) Characterization and cadmium-resistant gene expression of biofilm-forming marine bacterium Pseudomonas aeruginosa JP-11. Environ Sci Pollut Res 21:14188-14201.

13. Choi A, Wang S, Lee M (2009) Biosorption of cadmium, copper, and lead ions from aqueous solutions by Ralstonia sp. and Bacillus sp. isolated from diesel and heavy metal contaminated soil.Geosci J 13:331-341.

14. Chouhan S, Tuteja U, Flora SJ (2012) Isolation, identification and characterization of fluoride resistant bacteria: possible role in bioremediation. Appl BiochemMicrobiol 48:43-50. 
15. Chudobova D, Dostalova S, Ruttkay-Nedecky B, Guran R, Rodrigo MA, Tmejova K, Krizkova S, Zitka O, Adam V, Kizek R (2015) The effect of metal ions on Staphylococcus aureus revealed by biochemical and mass spectrometric analyses. Microbiol Res 170:147-156.

16. Cornu JY, Huguenot D, Jézéquel K, Lollier M, Lebeau T (2017) Bioremediation of copper-contaminated soils by bacteria. World J Microbiol Biotechnol33:26.

17. De J, Ramaiah N, Vardanyan L (2008) Detoxification of toxic heavy metals by marine bacteria highly resistant to mercury. Mar Biotechnol 10:471-477.

18. Devika L, Rajaram R, Mathivanan K (2013) Multiple heavy metal and antibiotic tolerance bacteria isolated from equatorial Indian Ocean. Int JMicrobiol Res 4:212-218.

19. Dhaliwal SS, Singh J, Taneja PK, Mandal A (2020) Remediation techniques for removal of heavy metals from the soil contaminated through different sources: a review. Environ Sci Pollut Res 27:1319-1333.

20. Dickinson AW, Power A, Hansen MG, Brandt KK, Piliposian G, Appleby P, O'neill PA, Jones RT, Sierocinski P, Koskella B, Vos M (2019) Heavy metal pollution and co-selection for antibiotic resistance: A microbial palaeontology approach. Environ Int132:105117.

21. Dimkpa CO, Zeng J, McLean JE, Britt DW, Zhan J, Anderson AJ (2012) Production of indole-3-acetic acid via the indole-3-acetamide pathway in the plant-beneficial bacterium Pseudomonas chlororaphis 06 is inhibited by $\mathrm{ZnO}$ nanoparticles but enhanced by CuO nanoparticles. Appl Environ Microbiol 78:1404-14010.

22. Fan M, Liu Z, Nan L, Wang E, Chen W, Lin Y, Wei G (2018) Isolation, characterization, and selection of heavy metalresistant and plant growth-promoting endophytic bacteria from root nodules of Robiniapseudoacacia in a $\mathrm{Pb} / \mathrm{Zn}$ mining area.Microbiol Res217:51-59.

23. Fashola MO, Ngole-Jeme VM, Babalola $O O$ (2020) Heavy metal immobilization potential of indigenous bacteria isolated from gold mine tailings. Int J Environ Res 14:71-86.

24. Ghaed S, Shirazi EK, Marandi R (2013) Biosorption of copper ions by Bacillus and Aspergillus species. Adsorp Sci Technol 31:869-890.

25. Giri S, Singh AK (2017) Human health risk assessment due to dietary intake of heavy metals through rice in the mining areas of Singhbhum Copper Belt, India. Environ Sci Pollut Res 24:14945-14956.

26. Glick BR (2010) Using soil bacteria to facilitate phytoremediation.Biotechnol Adv 28:367-374.

27. Hadiani MR, Darani KK, Rahimifard N, Younesi H (2018) Biosorption of low concentration levels of Lead (II) and Cadmium (II) from aqueous solution by Saccharomyces cerevisiae: Response surface methodology. Biocatal Agric Biotechnol 15:25-34.

28. Halder U, Banerjee A, Biswas R, Sharma A, Pal S, Adhikary A, Bandopadhyay R (2020) Production of prodigiosin by a drug-resistant Serratia rubidaea HB01 isolated from sewage. Environ Sustain 3:279-287.

29. Heidari P, Mazloomi F, Sanaeizade S (2020) Optimization study of nickel and copper bioremediation by microbacteriumoxydans strain CM3 and CM7. Soil Sediment Contam 29:438-51.

30. Heo SJ, Park EJ, Lee KW, Jeon YJ (2005) Antioxidant activities of enzymatic extracts from brown seaweeds. BioresourTechnol 96:1613-23.

31. Jalloh MA, Chen J, Zhen F, Zhang G (2009) Effect of different N fertilizer forms on antioxidant capacity and grain yield of rice growing under Cd stress. J Hazard Mater162:1081-1085.

32. Kang W, Zheng J, Bao J, Wang Z, Zheng Y, He JZ, Hu HW (2020) Characterization of the copper resistance mechanism and bioremediation potential of an Acinetobacter calcoaceticus strain isolated from copper mine sludge. Environ Sci Pollut Res 27:7922-7933.

33. Karthik C, Barathi S, Pugazhendhi A, Ramkumar VS, Thi NB, Arulselvi PI (2017) Evaluation of Cr (VI) reduction mechanism and removal by Cellulosimicrobiumfunkei strain AR8, a novel haloalkaliphilic bacterium. J Hazard Mater 
333:42-53.

34. Kokes $\mathrm{H}$, Morcali MH, Acma E (2014) Dissolution of copper and iron from malachite ore and precipitation of copper sulfate pentahydrate by chemical process. Eng Sci Technol an Int J 17:39-44.

35. Kumar S, Stecher G, Tamura K (2016) MEGA7: molecular evolutionary genetics analysis version 7.0 for bigger datasets. Mol BiolEvol 33:1870-1874.

36. Magnani D, Solioz M (2007) How bacteria handle copper. In: Molecular microbiology of heavy metals. Springer, Berlin, Heidelberg, pp 259-285

37. Mehes-Smith M, Nkongolo KK (2015) Physiological and cytological responses of Deschampsiacespitosa and Populus tremuloides to soil metal contamination. Water Air Soil Pollut226:1-2.

38. Menasria T, Monteoliva-Sánchez M, Benammar L, Benhadj M, Ayachi A, Hacène H, Gonzalez-Paredes A, Aguilera M (2019) Culturable halophilic bacteria inhabiting Algerian saline ecosystems: a source of promising features and potentialities. World J MicrobiolBiotechnol 35:1-6.

39. Mills SD, Lim CK, Cooksey DA (1994) Purification and characterization of CopR, a transcriptional activator protein that binds to a conserved domain (cop box) in copper-inducible promoters of Pseudomonas syringae.Mol Gen Genet 244:341-351.

40. Minegishi H (2013) Halophilic, acidophilic, and haloacidophilic prokaryotes. In: Polyextremophiles, Springer, Dordrecht, pp 201-213

41. Murthy S, Bali G, Sarangi SK (2014) Effect of lead on growth, protein and biosorption capacity of Bacillus cereus isolated from industrial effluent. J Environ Biol 35(2):407-411

42. Naguib MM, Khairalla AS, El-Gendy AO, Elkhatib WF (2019) Isolation and characterization of mercury-resistant bacteria from wastewater sources in Egypt. Can J Microbiol 65:308-321.

43. Ngole-Jeme VM (2017) Changes in the Mineralogy and Geochemistry of mine tailings contaminated soil as a result of fire events and the Implications on soil sorption properties. In: international conference on environmental pollution control, pp 8-12

44. Palanivel TM, Sivakumar N, Al-Ansari A, Victor R (2020) Bioremediation of copper by active cells of Pseudomonas stutzeri LA3 isolated from an abandoned copper mine soil. J EnvironManag 253:109706.

45. Prior RB, Perkins RL (1974) Artifacts induced by preparation for scanning electron microscopy in Proteus mirabilis exposed to carbenicillin. Can JMicrobiol 20(5):794-795

46. Rajaram R, Banu JS, Mathivanan K (2013) Biosorption of Cu (II) ions by indigenous copper-resistant bacteria isolated from polluted coastal environment.Toxicol Environ Chem 95:590-604.

47. Rathaur P, Ramteke PW, Raja W, John SA (2012) Isolation and characterization of nickel and cadmium tolerant plant growth promoting rhizobacteria from rhizosphere of Withaniasomnifera. J Biol Environ Sci6:253-261.

48. Reddy CA, Beveridge TJ, Breznak JA, Marzluf G (2007) Methods for general and molecular microbiology, $3^{\text {rd }}$ edn. ASM Press, New York, Washington, DC

49. Ruixia L, Jianhua P, Hongxiao T, LoWaihung T (2002) Biosorption mechanism of Cu (II) on Microccus luteus biomass. Environ Chem 21:50-55.

50. Saitou N, Nei M (1987) The neighbor-joining method: a new method for reconstructing phylogenetic trees. Mol BiolEvol 4:406-425.

51. Schiraldi C, De Rosa M (2014) Mesophilic organisms. In: Drioli E, Giorno L (eds) Encyclopedia of Membranes. Springer, Berlin, Heidelberg

52. Shahla SN, Mohammad RK, Giti E, Mehdi YM, Shahryar S, Maryam F (2014) Molecular analysis of copper resistance determinant (copA) in copper oxide nanoparticles resistant Pseudomonas fluorescens CuO-2 isolated from soil. Int JBiosci5:97-104.

Page $12 / 21$ 
53. Shreya D, Jinal HN, Kartik VP, Amaresan N (2020) Amelioration effect of chromium-tolerant bacteria on growth, physiological properties and chromium mobilization in chickpea (Cicer arietinum) under chromium stress. Arch Microbiol 202:887-94.

54. Sofy MR, Seleiman MF, Alhammad BA, Alharbi BM, Mohamed HI (2020) Minimizing adverse effects of pb on maize plants by combined treatment with jasmonic, salicylic acids and proline. Agron 10:699.

55. Stewart LJ, Thaqi D, Kobe B, McEwan AG, Waldron KJ, Djoko KY (2019) Handling of nutrient copper in the bacterial envelope. Metallomics 11:50-63.

56. Theriappan P, Gupta AK, Dhasarrathan P (2011) Accumulation of proline under salinity and heavy metal stress in cauliflower seedlings. J Appl Sci Environ Manage 15: 251 - 255.

57. Thurman RB, Gerba CP, Bitton G (1989) The molecular mechanisms of copper and silver ion disinfection of bacteria and viruses. Crit Rev Environ Sci Technol 18:295-315.

58. Tiquia-Arashiro S, Rodrigues D (2016) Alkaliphiles and acidophiles in nanotechnology. In: Extremophiles: Applications in Nanotechnology, Springer, Cham

59. Tirry N, Joutey NT, Sayel H, Kouchou A, Bahafid W, Asri M, El Ghachtouli N (2018) Screening of plant growth promoting traits in heavy metals resistant bacteria: prospects in phytoremediation. J Genet EngBiotechnol 16:613619.

60. Tunali S, Çabuk A, Akar T (2006) Removal of lead and copper ions from aqueous solutions by bacterial strain isolated from soil. Chem Eng J 115:203-211.

61. ÜreyenEsertaş ÜZ, Uzunalioğlu E, Güzel Ş, Bozdeveci A, AlpayKaraoğlu Ş (2020) Determination of bioremediation properties of soil-borne Bacillus sp. 505Y11 and its effect on the development of Zea mays in the presence of copper. Arch Microbiol 202:1817-29.

62. Ye J, Yin H, Xie D, Peng H, Huang J, Liang W (2013) Copper biosorption and ions release by Stenotrophomonas maltophilia in the presence of benzo [a] pyrene. Chem Eng J 219:1-9.

63. Zhappar NK, Shaikhutdinov VM, Kanafin YN, Ten OA, Balpanov DS, Korolkov IV, Collinson SR, Erkasov RS, Bakibaev AA (2019) Bacterial and chemical leaching of copper-containing ores with the possibility of subsequent recovery of trace silver. Chem Pap 73:1357-1367.

\section{Tables}

Table 1 Basic properties of soil samples from four different sites 


\begin{tabular}{|c|c|c|c|c|}
\hline Soil property & Site-1 & Site-2 & Site-3 & Site-4 \\
\hline Organic matter (\%) & 2.32 & 0.43 & 3.26 & 2.19 \\
\hline Bulk density (g/cc) & 1.77 & 1.45 & 1.65 & 1.69 \\
\hline Moisture content (\%) & 1.92 & 1.15 & 2.23 & 1.36 \\
\hline CEC (meq/100g) & 12.35 & 16.33 & 17.45 & 13.99 \\
\hline AEC (meq/100g) & 1.24 & 1.26 & 0.24 & 0.45 \\
\hline $\mathrm{pH}$ & 6.54 & 8.26 & 5.56 & 6.47 \\
\hline Clay (\%) & 26.32 & 27.23 & 45.23 & 12.3 \\
\hline Silt (\%) & 45.66 & 16.23 & 29.32 & 65.23 \\
\hline Sand (\%) & 28.02 & 56.54 & 25.45 & 22.47 \\
\hline Nitrogen (\%) & 0.41 & 0.69 & 1.16 & 0.56 \\
\hline Potassium (mg/kg) & 24.32 & 11.49 & 7.56 & 13.89 \\
\hline Phosphate (mg/kg) & 78.36 & 22.65 & 64.35 & 33.14 \\
\hline Sodium (mg/kg) & 1.23 & 2.56 & 6.89 & 12.55 \\
\hline Magnesium (mg/kg) & 0.56 & 0.45 & 1.25 & 0.89 \\
\hline Sulphur (\%) & 1.79 & 2.21 & 1.63 & 1.52 \\
\hline Copper (\%) & 1.12 & 1.87 & 0.87 & 0.92 \\
\hline Iron (\%) & 10.03 & 8.74 & 7.68 & 8.15 \\
\hline Nickel (ppm) & 212 & 318 & 264 & 218 \\
\hline Lead (ppm) & 28 & 32 & 24 & 23 \\
\hline
\end{tabular}

Table 2 Phenotypic and Biochemical characterisation of CTB 
$\begin{array}{lll}\text { GKSM2 GKSM6 } & \text { GKSM11 }\end{array}$

\begin{tabular}{llll}
\hline Colony morphology. & & & \\
\hline Shape & Circular & Irregular & Punctiform \\
\hline Appearance & Dull & Glistening & Glistening \\
\hline Optical property & Opaque & Opaque & Translucent \\
\hline Elevation & Raised & Umbonate & Raised \\
\hline Texture & Moist & Viscid & Moist \\
\hline Margin & Entire (smooth) & Undulate (wavy) & Entire (smooth) \\
\hline Pigmentation & Creamy & Tan & Creamy \\
\hline Citrate utilization & - & + & - \\
\hline Extracellular enzyme & & & \\
\hline Catalase & + & + & + \\
\hline Amylase & + & + & - \\
\hline Protease & + & + & - \\
\hline Esterase & + & + & + \\
\hline Carbohydrate utilization & & + & + \\
\hline Triple sugar iron & - & + & + \\
\hline Fructose & + & + & + \\
\hline Mannitol & + & + & + \\
\hline Galactose & & + & + \\
\hline
\end{tabular}

* Positive result is indicated by ' + ' and negative result indicated by '-'

Table 3 Antibiotic susceptibility assay of CTB

Inhibition Zones (IZ) in mm

\begin{tabular}{lllllllllll}
$\begin{array}{l}\text { Bacterial } \\
\text { Strain }\end{array}$ & $\mathrm{E}$ & $\mathrm{S}$ & $\mathrm{CEC}$ & $\mathrm{MZ}$ & $\mathrm{P}$ & $\mathrm{FLC}$ & $\mathrm{AMX}$ & AMP & CTR & LE \\
& $\mathbf{( 1 5 \mathrm { mg } )}$ & $\mathbf{( 1 0 \mathrm { mg } )}$ & $\mathbf{( 3 0 / 1 0 \mathrm { mg } )}$ & $\mathbf{( 7 5 \mathrm { mg } )}$ & $\mathbf{( 1 0 \mathrm { mg } )}$ & $\mathbf{( 2 5 \mathrm { mg } )}$ & $\mathbf{( 1 0 \mathrm { mg } )}$ & $\mathbf{( 1 0 \mathrm { mg } )}$ & $\mathbf{( 3 0 \mathrm { mg } )}$ & $\mathbf{( 5 \mathbf { m g } )}$ \\
\hline Gksm2 & 24.5 & 19 & 28 & 22 & 18 & $\mathrm{R}$ & 20 & 22.5 & 28 & 22 \\
\hline Gksm6 & 22 & 19 & 34 & 34 & 36 & $\mathrm{R}$ & 32 & 35 & 31 & 21 \\
\hline Gksm11 & $\mathrm{R}$ & 15 & 24 & $\mathrm{R}$ & $\mathrm{R}$ & $\mathrm{R}$ & $\mathrm{R}$ & $\mathrm{R}$ & 21 & 25
\end{tabular}

*Antibiotic resistance (below $10 \mathrm{~mm}$ inhibition zone) denoted by ' $\mathrm{R}$ '

Table 4 Plant growth-stimulating attributes of CTB in presence and absence of copper 


\begin{tabular}{|c|c|c|c|c|c|c|c|c|}
\hline \multirow[t]{2}{*}{ Strain } & & \multirow{2}{*}{$\begin{array}{l}\text { IAA } \\
(\mu \mathrm{g} / \mathrm{ml})\end{array}$} & \multirow{2}{*}{$\begin{array}{l}\mathrm{GA}_{3} \\
(760 \mathrm{~nm})\end{array}$} & \multirow{2}{*}{$\begin{array}{l}\text { Pro } \\
\text { (520nm) }\end{array}$} & \multirow[t]{2}{*}{$\mathrm{NH}_{3}$} & \multirow[t]{2}{*}{$\mathrm{N}_{2}$-Fixation } & \multicolumn{2}{|c|}{ Antioxidant activity (\%) } \\
\hline & & & & & & & Residual & Inhibited \\
\hline \multirow[t]{2}{*}{ GKSM2 } & Control & $32 \pm 2.8$ & 0.545 & 0.697 & + & + & 30.2 & 69.8 \\
\hline & Treated & $48 \pm 3.2$ & 0.433 & 0.524 & + & + & 33.2 & 66.8 \\
\hline \multirow[t]{2}{*}{ GKSM6 } & Control & $16 \pm 2.1$ & 0.915 & 0.887 & + & + & 28.6 & 71.4 \\
\hline & Treated & $18 \pm 2.0$ & 0.750 & 0.846 & + & + & 31.3 & 68.7 \\
\hline \multirow[t]{2}{*}{ GKSM11 } & Control & $15 \pm 1.8$ & 0.872 & 0.701 & + & + & 29.2 & 70.8 \\
\hline & Treated & $12 \pm 1.3$ & 0.730 & 0.618 & + & + & 32.1 & 77.9 \\
\hline
\end{tabular}

*Data are the mean of three replicates \pm SD. Presence of ' + ' indicated a positive result for the experiment

\section{Figures}



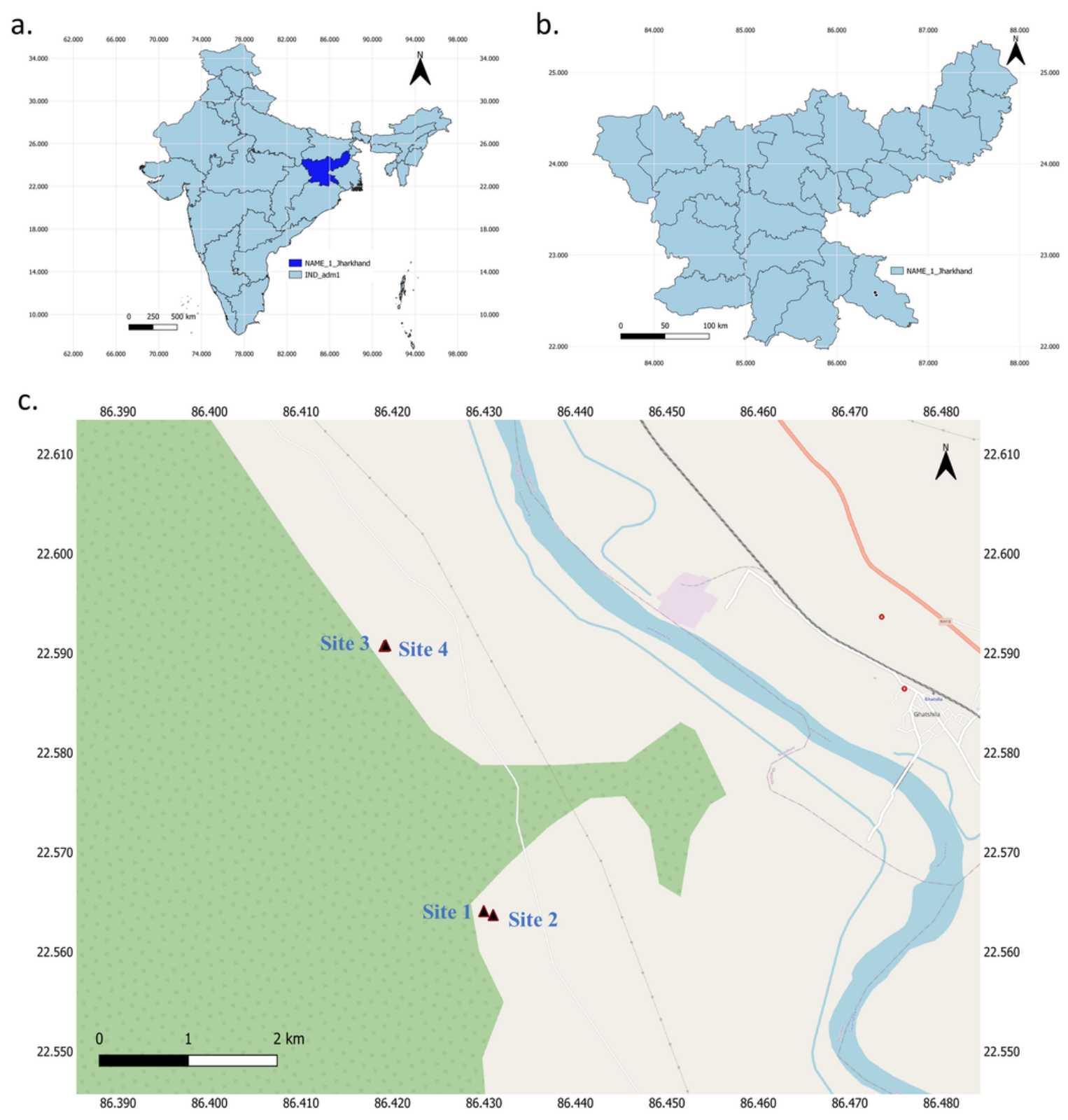

\section{Figure 1}

Q-GSI map showing study areas and their reference location (a) Jharkhand location in India (b) Jharkhand state (c) Four sampling sites 


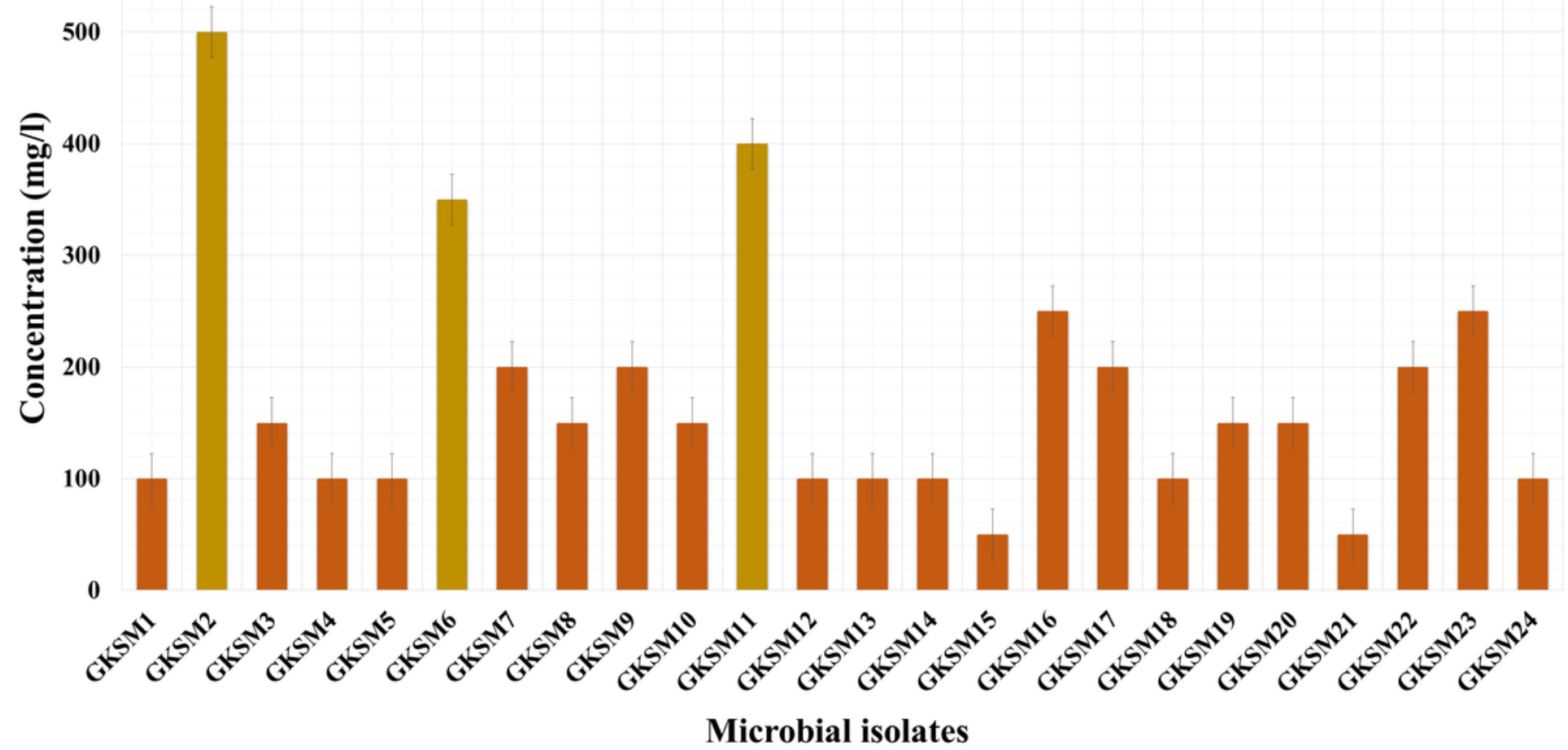

Figure 2

Maximum tolerable concentration $(\mathrm{mg} / \mathrm{l})$ of bacterial isolates against copper sulfate pentahydrate. Data are the mean of three replicates \pm SD represented as error bars
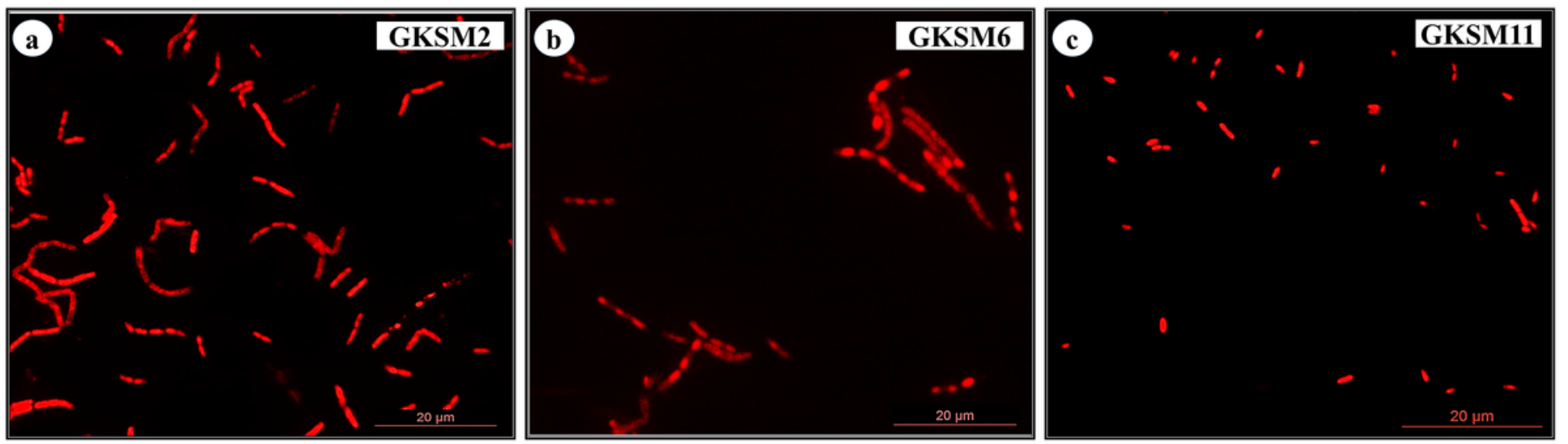

Figure 3

Fluorescence micrographs of CTB 


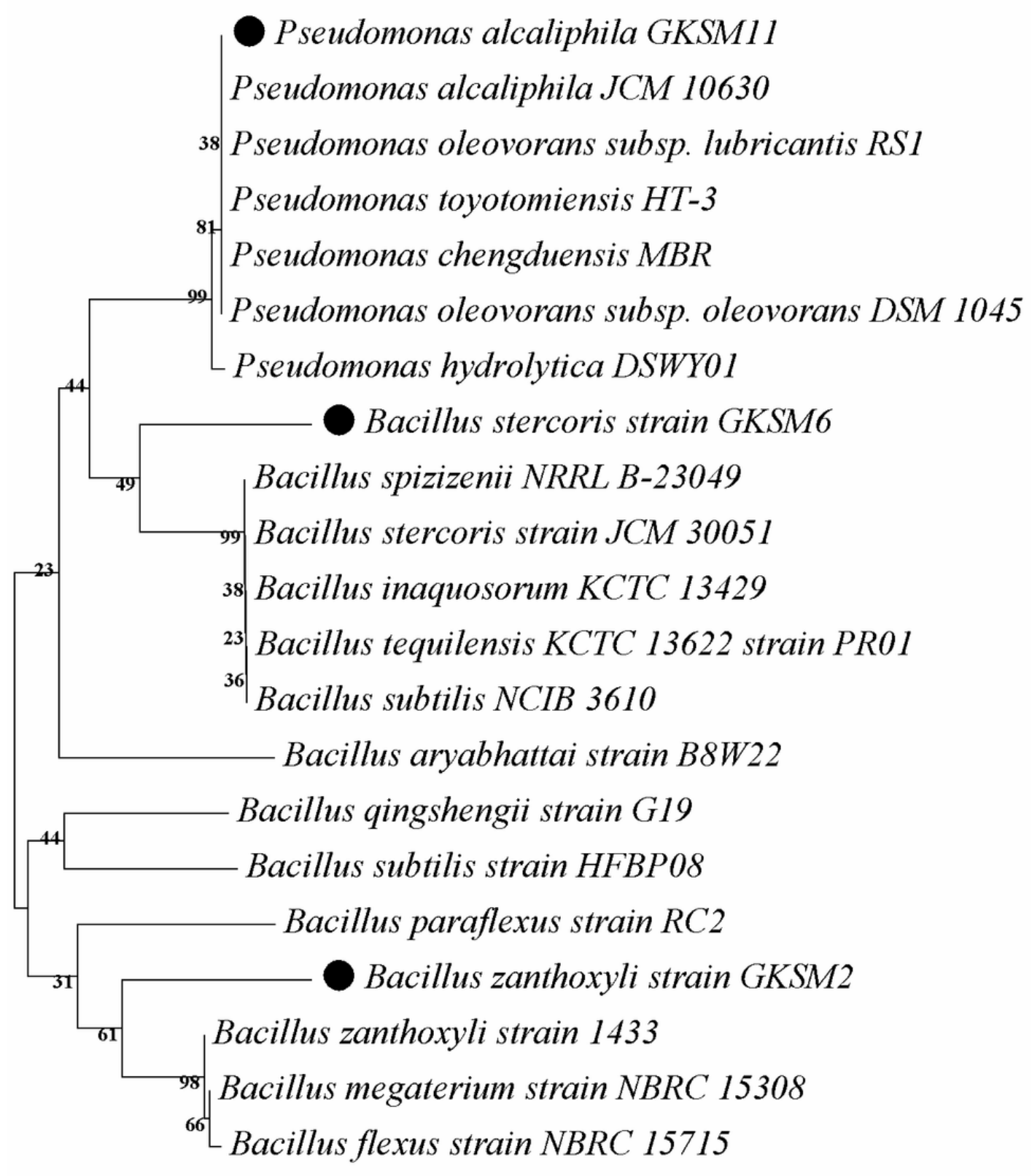

$\overleftrightarrow{0.5}$

Figure 4

Phylogenetic tree of CTB constructed from 16S rRNA gene sequences using neighbor-joining dendrogram method on MEGA version 7.0.26 software, verified with 500 bootstrapping replicates 


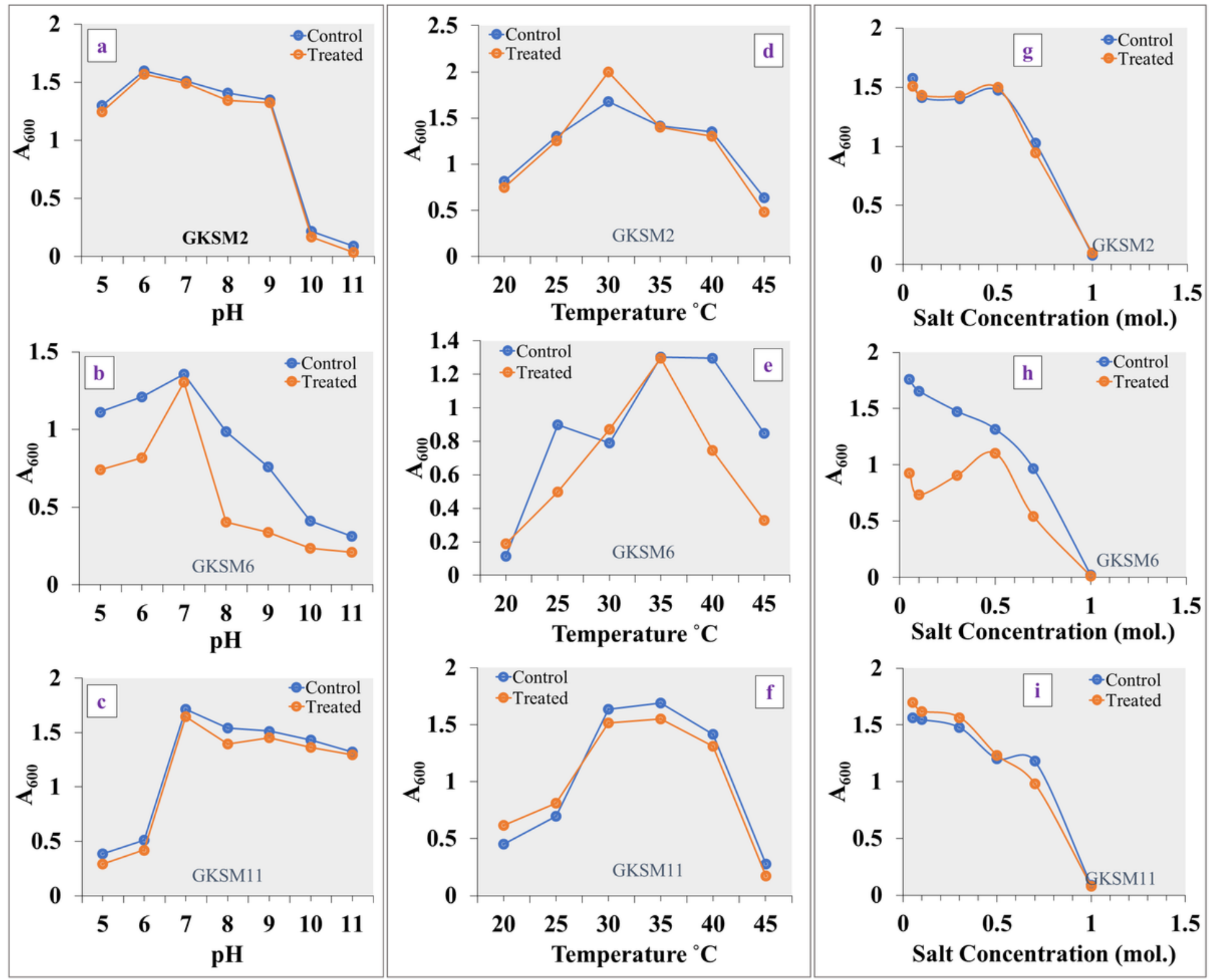

Figure 5

Growth patterns of three CTB (OD at $600 \mathrm{~nm})$ in presence and absence of copper with varying range of $\mathrm{pH}(\mathrm{a}-\mathrm{c})$, temperature $(\mathrm{d}-\mathrm{f})$ and salt concentration $(\mathrm{g}-\mathrm{i})$. Data are the mean of three replicates \pm SD represented as error bars 

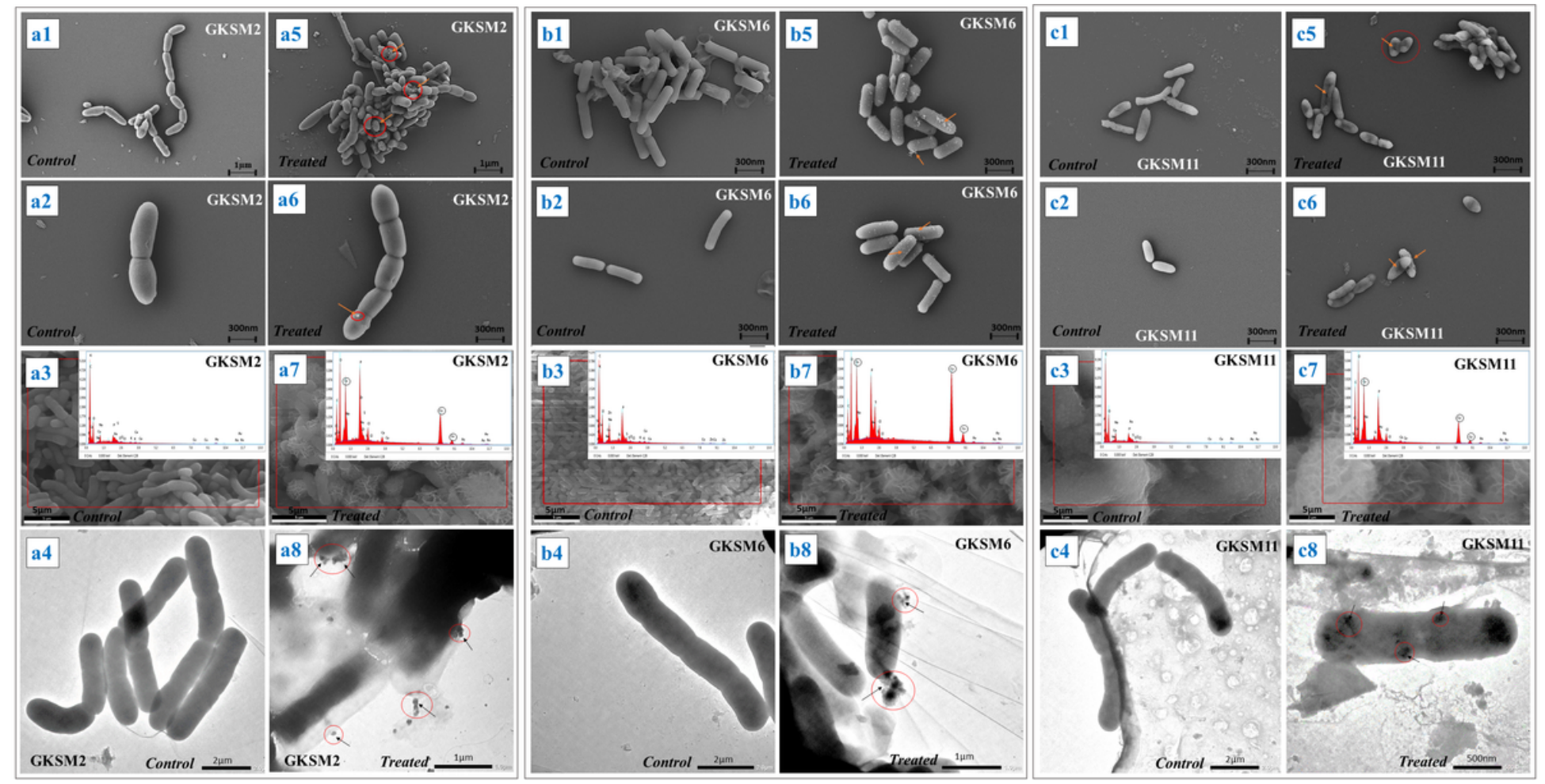

Figure 6

Scanning electron micrograph of CTB in presence and absence of copper (a1, a2, b1, b2, c1, c2) Control, (a5, a6, b5, b6, c5, c6) Treated; EDX spectrum of CTB: (a3, b3, c3) Control, (a7, b7, c7) Treated with copper peak; TEM observation of CTB: (a4, b4, c4) Control, (a8, b8, c8) Treated; Arrows indicated adsorption areas

\section{Supplementary Files}

This is a list of supplementary files associated with this preprint. Click to download.

- Tables1.docx 